\title{
Analysis of Talent Training Mode for Marketing Major in Chinese Colleges from Perspective of Corporate Demand for Talents
}

\author{
Weili Chen \\ Chongqing Technology and Business Institute, Chongqing, 400052, China
}

Keywords: Talent demand, Marketing, Talent training mode

\begin{abstract}
As economic development level keeps improving in China, quality-oriented education reform is being conducted deeply. Talent training of colleges should not just meet teaching objective, but also need to adapt social demand and industrial demand. Social demand becomes the driving force and objective of education reform and can decide the level and quality of professional talent training. As social production goes deep, the demand for marketing talents is on the rise. It is especially necessary to train marketing talents. This paper mainly analyzes current situations and methods of marketing talents in Chinese colleges, in the hope of offering some reference for relevant education departments.
\end{abstract}

\section{Introduction}

Marketing talents have been the talents urgently needed by the society. With continuous development of social economy, social demand for marketing talents strengthens constantly. Thus, higher requirements are proposed for the ability and attainment of marketing talents. But, most marketing talents only pay attention to learning theoretical courses and lack practical skills in training. Their operation ability is poor and they cannot adapt market demand. Thus, colleges must combine post demand to train the talents needed by society and enterprises during marketing talent training.

\section{Corporate demand for marketing talents}

\section{The demand for theoretical courses increases and owns very prominent "structure" contradiction}

At present, the demand for marketing talents is on the rise in many places. According to relevant survey, the quantity of marketing post recruitment in the whole society is $12 \%-15 \%$ of all posts. As both supply and demand expand continuously, the following phenomena appear: marketing talents in colleges grow every day, but enterprises cannot recruit suitable marketing talents. Thus, very serous contradiction between supply and demand appears. Such dual differences in talent structure and quality result in the shortage of marketing talents, and talent training quality is also poor ${ }^{[1]}$.

\section{Marketing post division gradually because detailed}

With stable and sustainable development of market economy, marketing is essential for both traditional manufacturing and emerging modern service industry. Marketing generates great influence in corporate and social effect as well as market effect. If marketing is consistent with social production demand and meets corporate production need, it can bring huge profits and positive market appeal. Marketing department in an enterprise expands and develops continuously, and the number of personnel increases all the time. In the past, marketing and marketing managers cannot adapt corporate development demand. Meanwhile, the post demand for emerging market survey, product planning, market promotion and consultation service is on the rise. In particular, the demand for marketing talents in coastal region and Yangtze River delta increases continuously. According to the survey of over 200 enterprises, marketing talents mainly include two types: sale and marketing management. Marketing management involves supporting personnel, market survey personnel, marketing planning personnel, network sale personnel and market promotion personnel. 


\section{Post ability of marketing major is diversified}

It is found from current enterprise survey that, marketing talents adopt very extensive working environment, and there are also numerous suitable jobs. They can not just engage in sale, marketing planning, market survey, customer management, import and export services, but also carry out marketing management and service agency etc. ${ }^{[2]}$ Since different post levels have differences, post ability also differs. Especially for marketing personnel, the emphasis is executive capacity. For marketing supervisors, the emphasis is marketing management and planning. Similarly, it is found from survey of the 200 enterprises that, marketing personnel need to own many abilities such as communication ability, promotion ability, negotiation ability, market analysis ability and marketing planning ability.

\section{Innovative practice ability becomes a key factor of marketing talent demand}

The survey shows in market demand factors of marketing talents, innovation spirit ad innovation ability are the most important factors in professional quality and occupy a large proportion in the total elements. For undergraduates, it is necessary to enhance cultivation of practical ability. Practical ability is considered as one of the most important abilities needed by enterprises. Hence, students can meet various requirements of enterprises and become real talents only through continuously improving practical ability, learning to study actively and train independently.

\section{Methods to train practice and innovation ability of marketing talents}

Marketing talent training involves many contents. Innovation and practice training should regard actual post demand as the key point, always focus on this demand and create marketing talent application characteristics and enhance training of comprehensive quality and application ability. Thus, colleges should actively expand market, survey the market and know real market demand. In this way, colleges can target talent training, continuously change talent training thought, find the new way suitable for marketing talent training, continuously innovate for traditional teaching mode, keep perfecting and enhancing practical ability training mode and continuously satisfy market demand for talents ${ }^{[3]}$.

\section{Show characteristic ability and set courses adapting post demand}

Training students to solve practical problems with basic theoretical knowledge is the key to innovation and practice ability training of marketing talents. Meanwhile, it is also an important objective. In accordance with different post requirements and diverse post level requirements, key contents and core contents of marketing talent training should satisfy corporate demand for talents. Next, sales promotion ability, negotiation ability, communication ability, market analysis ability and marketing planning ability serve as the core abilities according to actual needs of enterprises. Aiming at cultivation of the above abilities, the following course group is designed, as shown in Table 1. 
Table 1. Course design for core ability training of marketing talents

\begin{tabular}{|c|c|c|c|}
\hline Core ability & Theoretical courses & Practical teaching & $\begin{array}{l}\text { Comprehensive } \\
\text { practice platform }\end{array}$ \\
\hline Sales promotion ability & $\begin{array}{l}\text { Marketing Behavior, } \\
\text { Marketing Psychology, } \\
\text { Network Marketing }\end{array}$ & $\begin{array}{l}\text { Practical training of } \\
\text { marketing }\end{array}$ & Specialty practice \\
\hline Negotiation ability & $\begin{array}{c}\text { Consumer Psychology, } \\
\text { Business Negotiation, } \\
\text { Business } \\
\text { Communication, } \\
\text { Organizational } \\
\text { Behavior, Etiquette }\end{array}$ & $\begin{array}{l}\text { Consumer Psychology } \\
\text { course setting, business } \\
\text { negotiation simulation }\end{array}$ & Graduation thesis \\
\hline Market survey ability & $\begin{array}{l}\text { Market Survey and } \\
\text { Analysis, Statistics }\end{array}$ & $\begin{array}{c}\text { Market Survey course } \\
\text { setting }\end{array}$ & Graduation thesis \\
\hline Market analysis ability & Economics & $\begin{array}{c}\text { SPSS statistical } \\
\text { software practice }\end{array}$ & $\begin{array}{l}\text { Specialty association, } \\
\text { the second classroom }\end{array}$ \\
\hline $\begin{array}{l}\text { Marketing planning } \\
\text { ability }\end{array}$ & $\begin{array}{c}\text { advertising, Public } \\
\text { Relations, Practical } \\
\text { Writing }\end{array}$ & Public Relations course & $\begin{array}{c}\text { Practice in off-campus } \\
\text { practice base }\end{array}$ \\
\hline $\begin{array}{l}\text { Marketing management } \\
\text { ability }\end{array}$ & $\begin{array}{l}\text { Marketing, Marketing } \\
\text { Management, Customer } \\
\text { Relations, Marketing } \\
\text { Strategy Planning, } \\
\text { Service Marketing, } \\
\text { E-commerce, } \\
\text { Information } \\
\text { Management, Financial } \\
\text { Management, Human } \\
\text { Resource Management }\end{array}$ & $\begin{array}{l}\text { Comprehensive } \\
\text { simulation laboratory, } \\
\text { business simulation, } \\
\text { ERP sand table } \\
\text { simulation }\end{array}$ & $\begin{array}{l}\text { Industrial research and } \\
\text { development platform, } \\
\text { specialty competition }\end{array}$ \\
\hline
\end{tabular}

\section{Increase the proportion of practical teaching and training courses}

Based on the above analysis, we can know practice course is the key to marketing talent training and also a key link in teaching reform. Hence, it has important significance for training talents' practical ability. At present, in marketing talent training programs of most colleges, practical teaching occupies a very small proportion, while there are many theoretical courses. Theory often breaks away from practice. This imposes adverse impacts on talent training. Besides, class hours of practice course accounts for $30 \%$ of all class hours. Many enterprises indicate such college teaching mode which pays excessive attention to theory and neglects practical ability training is a very prominent issue and restricts development of students' innovation ability. It is very necessary to solve this problem. In foreign countries, many colleges are increasing class hours of practice course in marketing talent training programs, and the class hours accounts for $50 \%$ of total class hours. They really achieve balanced setting of theory and practice courses. Students various abilities are trained ${ }^{[4]}$. Thus, it is required to keeping increasing the proportion of practical teaching link. Comprehensive simulation experiment of marketing training and visit, and business simulation may be set. Besides, innovation training course may be organized regularly to really exert the functions of practical teaching. The application of professional knowledge and practical training can greatly shorten the gap between talent training and post demand.

\section{Pay attention to using behavior guidance teaching method in professional course teaching}

Usually, behavior guidance teaching attaches great importance to interactivity and interactivity. For the students majoring in marketing, practical ability, analysis ability, environmental adaptation ability and decision management ability are the key points of learning. Meanwhile, these are also the emphases of college talent training. These abilities will greatly help students for their future work. In fact, behavior guidance is a process of learning and teaching in the whole teaching process. Meanwhile, it is an interactive learning process of teachers and students. A complete teaching process is finished in the learning situation of mutual exchange and promotion. Simulation teaching method, 
case teaching method, project teaching method and situational teaching method in behavior guidance teaching may be used. The application of these teaching methods in marketing talent training not just improves teaching efficiency, but also enhances students' interest in courses in the specific teaching situation and breaks through many limitations of traditional teaching so that students can solve practical problems in marketing.

\section{Expand channels of students' innovative practice platform}

Organize marketing association. Students can not just learn professional courses in classroom

They have many ways to learn the courses they are interested in. The specialty association is a common learning organization, also called the second classroom. For the students majoring in marketing, practical ability training will be achieved through participation in association activities. Such independent operation and study will play a very important role. Under teachers' guidance, more extracurricular practical activities maybe organized to achieve combination of professional knowledge and practical skills as well as supplement of course contents. Association activities can motivate students' learning enthusiasm. Besides, students enhance teamwork ability through learning and practice together and highlight professional, individual and vocational features.

Organize students to participate in various professional skill competitions

Colleges may organize students to participate in various competitions. In competitions, students can learn advantages of other excellent students to improve their practical skills. Meanwhile, they can motivate their innovation ability and boost knowledge application ability. The competitions may include "challenge cup" business startup competition for college students and simulation contest etc.

Enhance service level of professional teachers and students with the help of industry-university-research platform

Industry-university-research platform in colleges is a comprehensive education platform which integrates academic exchange, academic discussion, academic report and research. Under such platform, students and teachers can carry out all kinds of marketing activities, such as market survey analysis and corporate consultation planning. Except enhancing teachers' professional service ability, these marketing activities can make more students participate, and continuously strengthen their interest in professional course discussion, entrepreneurial practice skills and innovation spirit.

\section{Pay attention to reforming teaching methods}

Repeat phenomenon cannot appear in preparing teaching materials of marketing major. In terms of knowledge structure, microcosmic knowledge and macroscopic knowledge should be combined. Macroscopic knowledge should be transformed to microcosmic knowledge as far as possible. In addition, teaching methods need to be adjusted continuously. Knowledge and ability should coexist. It is necessary to carry out dynamic allocation of knowledge capability teaching module, make traditional education mode become flexible and transform the situation of teachers' independent teaching and students passive listening. Teachers no longer give a lesson according to the textbook, but interact with students. Besides, teachers can combine foreign teaching experience to prepare scientific teaching contents according to students' learning effect, and smoothly transform dull and obscure theoretical knowledge to active classroom teaching ${ }^{[5]}$. At present, after teaching reform is finished, heuristic teaching, situational teaching and discussion teaching may be adopted to really teach students in accordance of their aptitude and highlight students' leading role. Students become the subject in teaching, instead of being teacher-centered or textbook-centered. Furthermore, professional module teaching should be established. Module teaching should be student-oriented and regard learning ability as vocational assessment standard. In line with post demand and ability division, skills are divided into different modules. Post skill training is conducted according to fixed steps. Correct teaching mode should be applied in marketing course. According to post features and object location, knowledge capability structure is divided into different modules, such as professional foundation, function marketing ability, marketing research and analysis ability as well as marketing planning and management ability etc. 


\section{Conclusions}

In one word, based on corporate demand for talents, college marketing talent training is a systematical job. Talent training involves many contents. Colleges should not merely carry out teaching reform, but also intensify infrastructure construction, teaching team building and cultural construction so as to offer support for students' ability cultivation. This paper analyzes the problems of marketing talent training and the methods and shows important functions of quality-oriented education reform in talent training and teaching.

\section{Acknowledgments}

This paper is phased research result of the topic Which name is Exploration and Practice of Marketing Talent Training Based on '123 Course’ Linkage (project No.: GZJG1411610).

\section{References}

[1] Hao Kening, Study on applied talent training mode of marketing major - case study of marketing major in Qilu Normal University . Journal of Qilu Normal University, 2013,28(3):5-9.

[2] Wang Zhaoyang, Study on "job market" talent training mode based on deep university-enterprise fusion - case study of marketing major in a university . Journal of Anhui Agricultural University (Social Sciences), 2014,23(3):118-122.

[3] Zhao Yanhua, Jia Aiying, SWOT analysis and development strategy selection of maketing major - based on Tianjin Urban Construction Institute . Chinese and Foreign Entrepreneurs, 2015(24):160-161,163.

[4] Wu Shijun, Chen Tao, Sun Wei etc., Study on practical teaching of marketing major and innovative talent training - case study of Wuhan University of Science and Technology . Commercial Economy, ,2012(17):62-64.

[5] Xiao Fei, Jing Lijua, Huang Yuanzheng etc., Study on practical teaching system of higher vocational marketing talent training based on ability orientation. Economic Research Guide, 2014(21):185-187. 